\title{
SEROPREVALENCE OF HEPATITIS B SURFACE ANTIGEN IN AN URBAN POPULATION OF NORTH EASTERN STATE
}

\author{
Debadatta Dhar Chanda1, Atanu Chakravarty ${ }^{2}$ \\ ${ }^{1}$ Associate Professor, Department of Microbiology, Silchar Medical College and Hospital, Silchar. \\ ${ }^{2}$ Assistant Professor, Department of Microbiology, Silchar Medical College and Hospital, Silchar.
}

\section{ABSTRACT}

Hepatitis B is a major public health problem worldwide due to its chronic manifestations like chronic hepatitis, cirrhosis and hepatocellular carcinoma. The most complete data providing a picture of hepatitis B disease burden come from seroprevalence study. Over the last several decades researchers have conducted many studies in different parts of India, but information and studies are very limited in North Eastern zone. Keeping this in mind, this study was undertaken to look for prevalence of Hepatitis B virus in an urban population of southeast Assam. This community based study was conducted from September 2013 to August 2015. A total of 688 blood samples were collected from 21 municipal wards of Silchar town and all samples were subjected to ELISA for detecting Hepatitis B Surface Antigen. Out of 688 samples, only 20 (2.9\%) were reactive, which is in accordance with Indian scenario.

\section{KEYWORDS}

Prevalence, Hepatitis B Surface Antigen, Urban Population.

HOW TO CITE THIS ARTICLE: Chanda DD, Chakravarty A. Seroprevalence of hepatitis B surface antigen in an urban population of north eastern state. J. Evolution Med. Dent. Sci. 2016;5(15):683-684, DOI: 10.14260/jemds/2016/157

\section{INTRODUCTION}

Hepatitis B is a major public health problem worldwide. Approximately, $30 \%$ of world's population or about 2 billion persons have serological evidence of either current or past infection with Hepatitis B virus. ${ }^{1}$ This infection is a leading cause of morbidity and mortality, not only because of acute illness but due to its chronic sequel like chronic hepatitis, cirrhosis and hepatocellular carcinoma accounting for more than a million death annually worldwide.2,3 The prevalence of chronic HBV infection in India ranges from $2-10 \%$ as shown by different studies. ${ }^{1}$

The countries with diverse ethnic groups may have markedly different HBV prevalence in different groups. ${ }^{4}$ Over the last several decades numerous researchers have conducted seroprevalence studies of HBV in India. ${ }^{1}$ Many of this studies are based on hospital patients. ${ }^{2}$ antenatal clinical patients. ${ }^{3,4}$ or voluntary blood donors. ${ }^{5}$ which do not really represent the general population. Keeping this in mind, this study was undertaken to look for prevalence in an urban community population of South East Assam to give some picture of HBV prevalence in this geographical area.

\section{MATERIALS AND METHODS}

This community based study was conducted during the period from September 2013 to August 2015. Institutional ethical clearance and permission for sample collection from Deputy Commissioner, Cachar District, Assam, was obtained before samples collection. Blood samples were collected from general population of Silchar town. Of the 28 Municipal wards or clusters of Silchar town, Cachar, Assam, 21 Clusters were selected by using "Proportionate to Population" (PPS) cluster technique.

Financial or Other, Competing Interest: None.

Submission 08-01-2016, Peer Review 04-02-2016,

Acceptance 09-02-2016, Published 19-02-2016.

Corresponding Author:

Dr. Debadatta Dhar Chanda,

Associate Professor, Department of Microbiology,

Silchar Medical College \& Hospital, Silchar,

Cachar, Assam.

E-mail: drdebadattadhar@rediffmail.com

DOI: $10.14260 /$ jemds/2016/157
Approximately 700 samples were decided to be collected (Statistically significant); so 30 to 35 samples were collected from each cluster. House to house survey was conducted and socio-demographic information was recorded. Total 688 samples were collected from apparently healthy persons of the household after getting informed consent. People with a history of Hepatitis B vaccination were excluded from study.

All blood samples were transported to Department of Microbiology, Silchar Medical College, by maintaining proper cold chain and were preserved in deep freeze $\left(-80^{\circ} \mathrm{C}\right)$. All specimens were subjected to Hepatitis B Surface Antigen ELISA test (ErbaLisa Hepatitis B). All reactive samples were repeat tested using the same ELISA kit. Samples showing repeat test reactivity were considered positive and were included for calculation of seroprevalence. Statistical analysis of the test results was done.

\section{RESULTS}

All specimens were subjected to Hepatitis B Surface Antigen ELISA test. Out of 688 samples, 20 were reactive which were further confirmed by repeat ELISA test. The overall prevalence was found to be $2.9 \%$ in this urban population. The prevalence of HBsAg among male subjects $(3.3 \%, 15 / 458)$ was higher than that among female subjects $(2.2 \%, 5 / 230)$. The majority of seropositive subjects were older than 35 years of age.

\begin{tabular}{|c|c|c|c|}
\hline $\begin{array}{c}\text { No. of } \\
\text { Samples } \\
\text { tested }\end{array}$ & \multicolumn{2}{|c|}{$\begin{array}{c}\text { Hepatitis B Surface } \\
\text { Antigen ELISA Test }\end{array}$} & $\begin{array}{c}\text { Prevalence of } \\
\text { Hepatitis } \\
\text { B Surface } \\
\text { Antigen }\end{array}$ \\
\hline & Reactive & $\begin{array}{c}\text { Non- } \\
\text { Reactive }\end{array}$ & \\
\hline 688 & 20 & 668 & $2.9 \%$ \\
\hline \multicolumn{3}{|c|}{$\begin{array}{c}\text { Table 1: Prevalence of Hepatitis B Surface } \\
\text { Antigen in the study population (n=688) }\end{array}$} \\
\hline
\end{tabular}




\begin{tabular}{|c|c|c|c|c|c|}
\hline \multirow{2}{*}{ Age } & \multicolumn{4}{|c|}{$\begin{array}{c}\text { Hepatitis B Surface Antigen } \\
\text { Prevalence }\end{array}$} & \multirow{2}{*}{ Total } \\
\hline \multirow{2}{*}{} & Positive & Negative & \\
\cline { 2 - 5 } & Nos. & $\%$ & Nos. & $\%$ & Nos. \\
\hline $15-20$ & 2 & 3 & 62 & 97 & 64 \\
\hline $20-30$ & 3 & 2.5 & 117 & 97.5 & 120 \\
\hline $30-40$ & 6 & 2.7 & 210 & 97.2 & 216 \\
\hline $40-50$ & 3 & 3 & 109 & 97.3 & 112 \\
\hline$>50$ & 6 & 3.4 & 170 & 96.6 & 176 \\
\hline $\begin{array}{r}\text { Table 2: Prevalence of Hepatitis B Surface Antigen with } \\
\text { respect to the age of subjects studied (n=688) }\end{array}$ \\
\hline
\end{tabular}

and with familial contact. Keeping this in mind further studies need to be done to assess vertical transmission. A large community based study is also required considering the diversity of social and cultural factors in the country, specially in North Eastern Zone.

\section{ACKNOWLEDGMENT}

This study is a part of ongoing project sponsored by the Indian Council of Medical Research (ICMR).

\section{BIBLIOGRAPHY}

1. World Health Organisation - Prevention of Hepatitis B in India: an overview. New Delhi: World Health Organisation, Regional Office for South-East Asia, 2002.

\begin{tabular}{|c|c|c|c|}
\hline Sex & \multicolumn{2}{|c|}{$\begin{array}{c}\text { Hepatitis B Surface } \\
\text { Antigen ELISA Test }\end{array}$} & $\begin{array}{c}\text { Prevalence of } \\
\text { Hepatitis } \\
\text { B Surface } \\
\text { Antigen }\end{array}$ \\
\hline & $\begin{array}{c}\text { No. of } \\
\text { samples } \\
\text { tested }\end{array}$ & Reactive & \\
\hline Male & 458 & 15 & $3.3 \%$ \\
\hline Female & 230 & 5 & $2.2 \%$ \\
\hline $\begin{array}{c}\text { Table 3: Prevalence of Hepatitis B Surface Antigen with } \\
\text { respect to sex of subjects studied (688) }\end{array}$ \\
\hline
\end{tabular}

2. Sood S, Malvankar S. Seroprevalence of Hepatitis B surface antigen, antibodies to Hepatitis $\mathrm{C}$ virus and human immunodeficiency virus in a hospital-based population in Jaipur, Rajasthan. Indian J of Community Med 2010 Jan ;35(1):165-169.

3. Singla N, Chander J. Seroprevalence of HBsAg in females in a North India tertiary care hospital with special reference to pregnancy. N Z Med J 2008 Jul 25th; 121(1278):105-6.

4. Narayanswamy K. Hepatitis B and pregnancy: challenges in India. JIMA October 2011;109(10):766-767.

5. Singh K, Bhat S, Shastry S. Trend in seroprevalance of Hepatitis B virus infection among blood donors of coastal Karnataka, India. J Infect Dev Ctries 2009;3(5):376-379.

This study is the first community based study of Hepatitis B Surface antigen prevalence in urban population of South East Assam. Statistically significant population sample was obtained by using suitable sampling methodology. The findings of the study indicate that the overall seroprevalence rate is $2.9 \%$, which is in accordance with the other parts of the country which has reported to vary from $2 \%$ to $7 \% .^{1}$ Similar observations were noted in another community based study done in our neighbouring state West Bengal by Chowdhury et al.(6) and they reported prevalence rate of $2.97 \%$. A higher prevalence of HBsAg (5.7\%) was found in a large community based study done in Tamil Nadu. ${ }^{7}$ Prevalence studies done in two urban population of South India had shown 3.3\% (Rajahmundry) and 4.2\% (Bangalore) respectively. ${ }^{8}$ a lower prevalence of $1.42 \%$ was found in an urban population based study of Ahmedabad city. ${ }^{9}$

A higher prevalence of HBsAg in males than in females is found in the present study. In another urban population based study more prevalence was found among male. ${ }^{9}$ a significant higher prevalence in males is also reported in other studies.5,10,11 the majority subjects having seropositive status are more than 35 years of age in the present study. In another community based study done in West Bengal also reported that positivity rate peaks in middle age. 6 Paediatric age groups were not included in this study, but the major spread of Hepatitis B virus in the community occurs during childhood

6. Chowdhury A, Santra A, Chakravorty R, et al. Community-based epidemiology of hepatitis B virus infection in West Bengal, India: prevalence of hepatitis B e antigen-negative infection and associated viral variants. J Gastroenterol Hepatol 2005 Nov;20(11): 1712 -20 .

7. Kurien T, Thyagarajan SP, Jeyaseelan L, et al. and STD Study Group. Community prevalence of hepatitis B infection and modes of transmission in Tamil Nadu, India. Indian J Med Res 2005 May;121(5):670-675.

8. Singh J, Bhatia R, Khare S, et al. Community studies on prevalence of $\mathrm{HbsAg}$ in two urban populations of Southern India. Indian Pediatrics 2000;37:149-152.

9. Bhagyalaxmi A, Lala MK, Jain S, et al. HBsAg carrier status in urban population of Ahmedabad city. Indian J Med Res 2005 March;121:203-204.

10. Chandrasekaran S, Palaniappan N, Krishnan V, et al. (2000). Relative prevalence of hepatitis B viral markers and hepatitis $\mathrm{C}$ virus antibodies (anti-HCV) in Madurai, South India. Indian J Med Sci 54:270-273.

11. Karki S, Ghimire P, Tiwari BR, et al. (2008). HBsAg serosurveillance among Nepalese blood donors. Annals of Tropical Medicine and Public Health 1:15-18. 